Tropical Journal of Pharmaceutical Research October 2018; 17 (10): 1919-1924

ISSN: $1596-5996$ (print); 1596-9827 (electronic)

(C) Pharmacotherapy Group, Faculty of Pharmacy, University of Benin, Benin City, 300001 Nigeria.

Available online at http://www.tjpr.org

Original Research Article

http://dx.doi.org/10.4314/tjpr.v17i10.4

\title{
7-Piperazine ethyl chrysin inhibits proliferation of lung cancer cells via induction of apoptosis
}

\author{
Di Li ${ }^{1}$, Lifei $\mathrm{Li}^{2}$, Lingzhan Wang ${ }^{3}$, Jianguo $\mathrm{Li}^{1}$, Bin Zhang ${ }^{4-6 *}$ \\ ${ }^{1}$ Department of Anatomy, The Medical College of Inner Mongolia University for the Nationalities, ${ }^{2}$ Respiratory Medicine, \\ Affiliated Hospital of Inner Mongolia University for the Nationalities, ${ }^{3}$ Institute of Applied Anatomy, ${ }^{4}$ Medicinal Chemistry and \\ Pharmacology Institute, Inner Mongolia University for Nationalities, ${ }^{5}$ Inner Mongolia Key Laboratory of Mongolian Medicine \\ Pharmacology for Cardio-Cerebral Vascular System, ${ }^{6}$ Affiliated Hospital of Inner Mongolia University for Nationalities, Institute \\ of Mongolia and Western Medicinal treatment, Inner Mongolia, 028000, China
}

*For correspondence: Email: BobbyyRobertskn@yahoo.com; Tel: 0086-0475-8314245

Sent for review: 7 June 2018

Revised accepted: 22 September 2018

\begin{abstract}
Purpose: To investigate the effect of 7-piperazine ethyl chrysin (PEC) on A-427 and A-549 lung cancer cell lines.

Methods: The cell lines were incubated with PEC at doses of 2, 4, 6, 8 and $10 \mu \mathrm{M}$ for 24, 48 and $72 \mathrm{~h}$, and their viabilities at each time interval were assessed using 3-(4,5-dimethylthiazol-2-yl)-2,5diphenyltetrazolium bromide (MTT) assay. Cell apoptosis was evaluated with annexin $V$ fluorescein isothiocyanate/propidium iodide staining, while the expression of ERK1/2 protein was determined using western blot. The involvement of ERK1/2 in the effect of PEC on viability and apoptosis was assessed by incubating the cells with PD98059 (an inhibitor of ERK1/2).

Results: Exposure to PEC at doses $\geq 4 \mu \mathrm{M}$ significantly reduced the viability of $A-427$ and A-549 cell lines in time- and concentration-dependent manners at $48 h(p<0.02)$. The viability of A-427 and A-549 cells was reduced to 21 and $18 \%$, respectively, on treatment with $8 \mu \mathrm{M}$ PEC for $48 \mathrm{~h}$. Moreover, PEC treatment induced apoptosis in A-427 (59.67\%) and A-549 (61.37\%) cells after $48 \mathrm{~h}$. Western blot data revealed that PEC also significantly inhibited phosphorylation of ERK1/2 in both cancer cell lines ( $p<$ 0.05). Incubation of A-427 and A-549 cells with PD98059 for $48 \mathrm{~h}$ also reduced their viability and induced their apoptosis $(p<0.05)$.

Conclusion: These results indicate that PEC inhibits the viability of lung cancer cells via inhibition of ERK1/2 expression. Thus, PEC may be efective for the treatment of lung carcinoma but further studies are required to ascertain this.
\end{abstract}

Keywords: 7-Piperazine ethyl chrysin, Lung cancer cells, Apoptosis, Viability, inhibition

\begin{abstract}
This is an Open Access article that uses a funding model which does not charge readers or their institutions for access and distributed under the terms of the Creative Commons Attribution License (http://creativecommons.org/licenses/by/4.0) and the Budapest Open Access Initiative (http://www.budapestopenaccessinitiative.org/read), which permit unrestricted use, distribution, and reproduction in any medium, provided the original work is properly credited.
\end{abstract}

Tropical Journal of Pharmaceutical Research is indexed by Science Citation Index (SciSearch), Scopus, International Pharmaceutical Abstract, Chemical Abstracts, Embase, Index Copernicus, EBSCO, African Index Medicus, JournalSeek, Journal Citation Reports/Science Edition, Directory of Open Access Journals (DOAJ), African Journal Online, Bioline International, Open-J-Gate and Pharmacy Abstracts

\section{INTRODUCTION}

Lung cancer is one of the leading causes of carcinoma-related deaths [1]. In 2008, about 10 lac cases of lung cancer were diagnosed throughout the world, resulting in 160,000 deaths in USA alone [2]. The regions most commonly affected by lung cancer include Southern America and Eastern parts of Asia and Europe [3]. The prognosis of lung cancer has improved 
over the years because of the development of comprehensive treatment strategies, amongst which is surgery. Although current treatments for lung cancer involve radical resection and chemotherapy (adjuvant), recurrence has been observed in majority of patients [3-5]. Thus, effective treatment for lung cancer is possible only through the discovery of novel anti-cancer drugs.

Apoptosis is the process of programmed cell death which plays an important role in removing unwanted cells from tissues [6,7]. In cancer, cells undergo uncontrolled division because of the failure of apoptosis. The regulation of cell apoptosis involves phosphorylation of various factors, including ERK1/2 [8]. It is known that ERK $1 / 2$ is a sub-group of the mitogen-activated protein kinases (MAPKs) which contribute to the survival of cancer cells [9].

It has been reported that phosphorylation of ERK1/2 triggered apoptosis in various types of cancer carcinoma cells [10]. Decreased activation of MAPK ERK1/2 in murine melanoma cells has also been reported to suppress the growth of these cells [11]. Studies have also demonstrated that the anti-proliferative effect of 5, 7-dimethoxycoumarin involves inhibition of ERK1/2 phosphorylation in the melanoma cell line model [12]. The present study was aimed at investigating the effect of PEC on lung cancer cells, and its mechanism of action.

\section{EXPERIMENTAL}

\section{Cell culture}

The A-427 and A-549 lung cancer cell lines were purchased from the American Type Culture Collection (ATCC; Rockville, MD, USA), and were cultured in DMEM containing FBS (10\%), glutamine $(2 \mathrm{mM})$, penicillin $(100 \mathrm{U} / \mathrm{mL})$ and streptomycin $(100 \mu \mathrm{g} / \mathrm{mL})$. The cells were cultured at $37{ }^{\circ} \mathrm{C}$ in an incubator in an atmosphere containing $5 \%$ carbon dioxide.

\section{Assay of cell proliferation}

The proliferation of A-427 and A-549 cells after incubation with PEC or PD98059 (Selleck Chemicals LLC, Shanghai, China) was determined using 3-(4, 5-dimethylthiazol-2-yl)-2, 5-diphenyltetrazolium bromide (MTT; SigmaAldrich) assay. The cell lines were cultured separately in 6-well plates (Nunc A/S Plastfabrikation, Roskilde, Denmark) in DMEM medium containing $10 \%$ FBS at a density of $1 x$ $10^{6}$ cells per well, and were incubated with varying concentrations of $\operatorname{PEC}(2,4,6,8$ and 10 $\mu \mathrm{M}$ ) for $72 \mathrm{~h}$. After incubation, $50 \mu \mathrm{L}$ of MTT (5 $\mu \mathrm{g} / \mathrm{mL}$ ) solution was added to each well and the plates were incubated for $2 \mathrm{~h}$. Then, dimethyl sulfoxide (DMSO, $150 \mu \mathrm{L}$ ) was added to each well plate to dissolve the formazan crystals formed. After $5 \mathrm{~min}$, the optical density (OD) of each well was read at $570 \mathrm{~nm}$ in an EL800 Universal Microplate Reader (BioTek Instruments, Inc., Winooski, VT, USA). The readings were used to determine cell proliferation.

\section{Determination of apoptosis}

Apoptosis in A-427 and A-549 cells was determined after $48 \mathrm{~h}$ of treatment with PEC using an annexin V-FITC/PI apoptosis assay kit (Major BioTech Co., Ltd., Shanghai, China). Untreated (control) and PEC-treated cells were subjected to trypsinization after harvesting and subsequently washed using phosphate-buffered saline (PBS). The washed cells were centrifuged for $10 \mathrm{~min}$ at $500 \mathrm{xg}$ to remove the supernatant fraction. The resultant suspension was incubated for 20 min with annexin V-FITC $(20 \mathrm{~mL})$ and PI $(20 \mathrm{~mL})$ in the dark at room temperature, after which the cells were examined using flow cytometry (Beckman Coulter, Inc., Miami, FL, USA). The data obtained was analysed with WinMDI 2.9 (Purdue University Cytometry Laboratories, West Lafayette, USA). The experiments were performed in triplicate.

\section{Matrigel invasion assay}

Invasion of A-427 and A-549 cells was assessed using Transwell chambers pre-coated with 1 $\mathrm{mg} / \mathrm{mL}$ Matrigel matrix (40 $\mu \mathrm{L}$, BD Bioscience, Bedford, MA, USA). The cells $\left(1 \times 10^{5}\right)$ were trypsinized after $48 \mathrm{~h}$ of treatment with PEC, and subsequently put into the upper wells containing serum-free medium. The lower well contained medium with $10 \%$ FBS alone. After incubation for $12 \mathrm{~h}$, the cells on the Matrigel side of the chambers were cleaned using cotton swab. The cells were then fixed with methyl alcohol and subsequently stained with haematoxylin and eosin ( $H$ \& E). The invaded cells were quantified with a light microscope in eight random fields at x200 magnification. The calculations were carried out in triplicate.

\section{Western blot assay}

Following $48 \mathrm{~h}$ of PEC treatment, the A-427 and A-549 cells were collected and washed with PBS. The cells were then lysed in cold lysis buffer and subsequently incubated for $30 \mathrm{~min}$ on ice. The lysates were centrifuged for $15 \mathrm{~min}$ at 
$12,000 \times \mathrm{g}$ at of $4{ }^{\circ} \mathrm{C}$, and the protein concentration of the supernatant was determined using Bicinchoninic Acid Protein Assay kit (Pierce, Rockford, IL, USA) according to the instructions of the manufacturer. Protein samples $(50 \mu \mathrm{g})$ were separated by electrophoresis on 12 $\%$ sodium dodecyl sulphate-polyacrylamide gel.

The samples were then transferred onto polyvinylidene difluoride (PVDF) membranes (Bio-Rad Laboratories, Hercules, CA, USA) by a semidry transfer system. The membranes were blocked using bovine serum albumin (BSA, $5 \%$ ) and Tris-buffered saline with Tween ${ }^{\circledR} 20$ buffer at room temperature. Thereafter, the membranes were incubated with rabbit anti-human ERK and p-ERK polyclonal antibodies overnight at $4{ }^{\circ} \mathrm{C}$. Then, they were washed twice with phosphatebuffered saline (PBS) and incubated for $1 \mathrm{~h}$ with horseradish peroxidase (HRP)? ?conjugated secondary antibodies. The resultant immunoblots were visualized with enhanced chemiluminescence (LAS4000).

\section{Statistical analysis}

Data are presented as mean \pm standard deviation (SD) of three experiments carried out independently. Analyses of data was made using Student's $t$-test and one-way analysis of variance (ANOVA). All statistical analysis were carried out with SPSS, version 15.0 (SPSS, Inc., Chicago, IL, USA). Differences were taken as statistically significant at $p<0.05$.

\section{RESULTS}

\section{Anti-proliferative effect of PEC}

Exposure of A-427 and A-549 lung cancer cell lines to PEC led to significant reductions in their viabilities in time- and dose-dependent manners (Figure 1). The cell lines were incubated with PEC at doses of 2, 4, 6, 8 and $10 \mu \mathrm{M}$ for $72 \mathrm{~h}$, and cell viability was assessed after 24,48 and $72 \mathrm{~h}$ of incubation. It was observed that reduction of cell viability was significant $(p<0.02)$ with PEC doses $\geq 4 \mu \mathrm{M}$ at $48 \mathrm{~h}$. In $A-427$ cells, viabilities on treatment with 2, 4, 6, 8 and $10 \mu \mathrm{M}$ of PEC for $48 \mathrm{~h}$ were 99, 67, 43, 21 and $20 \%$, respectively, while the corresponding viabilities of A-549 cells at similar PEC doses were be 98, 62, 39,18 and $19 \%$, respectively at $48 \mathrm{~h}$ (Figure 1). However, the inhibition of viability of both cell lines was not significant at $24 \mathrm{~h}$ of treatment.

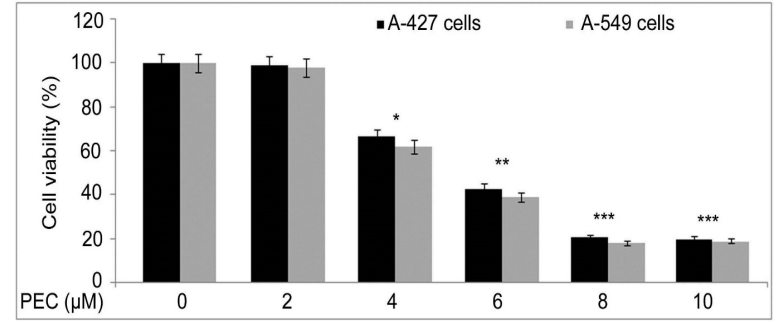

Figure 1: 7-Piperazine ethyl chrysin (PEC) reduced viabilities of $A-427$ and $A-549$ cell lines. Viability was determined with MTT assay after incubating the cells with various concentrations of PEC for different time periods. Data are expressed as mean \pm SD of three observations; ${ }^{*} p<0.05,{ }^{* *} p<0.02$ and ${ }^{* * *} p<0.01$, compared with untreated control cells

\section{PEC induced apoptosis in A-427 and A-549 lung cancer cell lines}

Apoptosis was determined in A-427 and A-549 cancer cell lines after incubation with 6 and $8 \mu \mathrm{M}$ PEC for $48 \mathrm{~h}$ by flow cytometry using annexin $\mathrm{V}-\mathrm{FITC} / \mathrm{PI}$ staining. The results clearly revealed that PEC treatment led to onset of apoptosis. The percentages of apoptosis in A-427 cells due to treatment with 6 and $8 \mu \mathrm{M}$ of PEC were 37.85 and $62.67 \%$, respectively, as against $1.54 \%$ apoptosis in the control (Figure 2). In A-427 cells, treatment with PEC at 6 and $8 \mu \mathrm{M}$ for $48 \mathrm{~h}$ resulted in 40.19 and $65.32 \%$ apoptosis, respectively, relative to $2.46 \%$ apoptosis in the control cells (Figure 2).

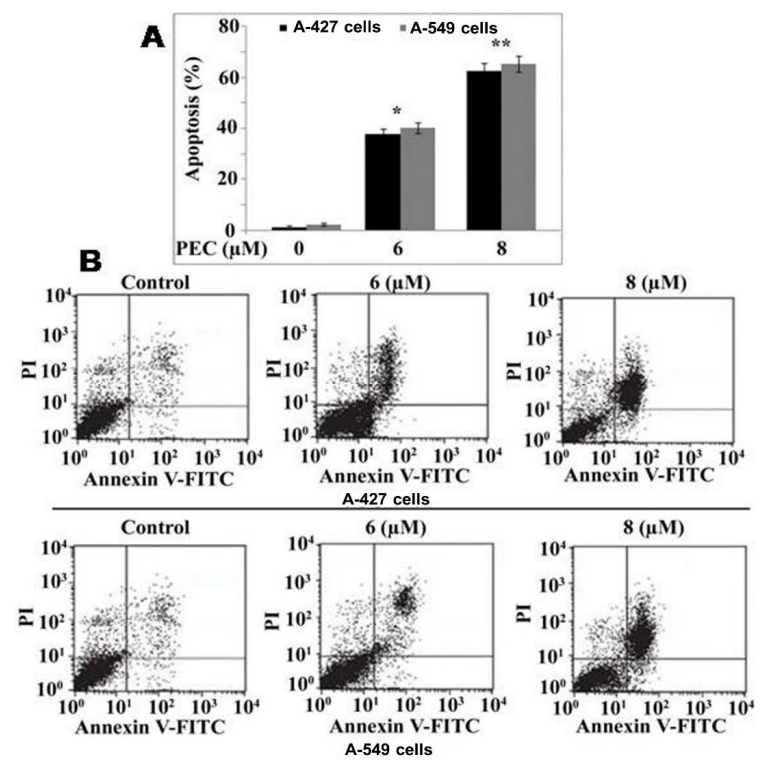

Figure 2: Induction of apoptosis in A-427 and A-549 lung cancer cell lines by PEC. A: Incubation of A-427 and A-549 cells with PEC at doses of 6 and $8 \mu \mathrm{M}$ for $48 \mathrm{~h}$ was followed by quantification of apoptosis using flow cytometry. B: Staining of the cells with annexin V-FITC)/PI followed by flow cytometric analysis 
PEC inhibited invasion in A-427 and A-549 lung cancer cells

Transwell assay was used to assess invasion of A-427 and A-549 lung cancer cells after incubation with PEC for $48 \mathrm{~h}$. The results showed that PEC treatment inhibited invasion in both cell lines in a concentration-dependent manner (Figure 3). Increase in the concentration of PEC from 2 to $8 \mu \mathrm{M}$ significantly reduced the invasion potential of A-427 and A-549 cells.
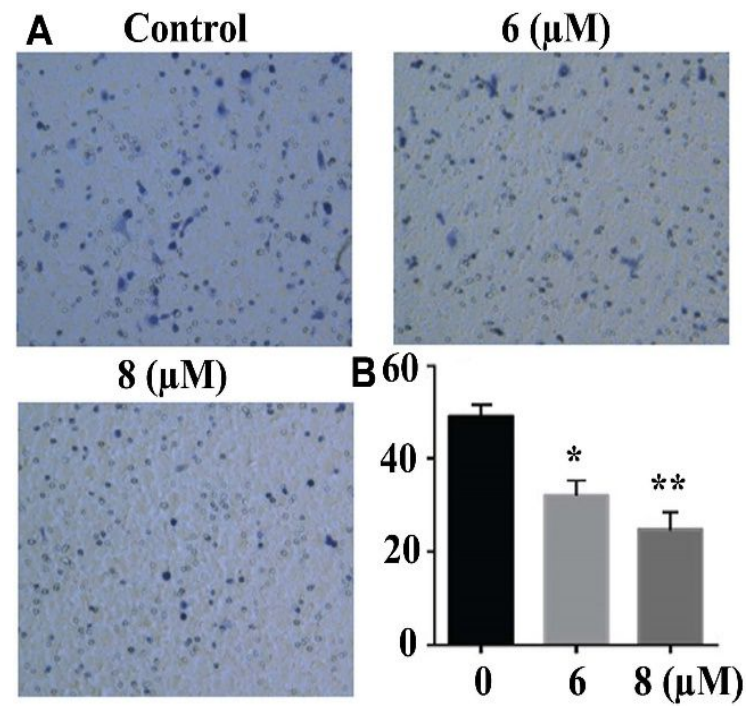

Figure 3: Inhibition of invasion of lung cancer cell lines by PEC. Invasion of the cells was assessed using Transwell assay after $48 \mathrm{~h}$ of treatment with PEC. A: $P E C$ reduced invasion of the cells through the membrane in a concentration-dependent manner (magnification, x400). B: Quantification of cells passing through the membrane; ${ }^{*} p<0.02,{ }^{* *} p<0.01$, compared with untreated cells (control)

\section{Effect of PEC on ERK1/2 activation}

The activation of ERK $1 / 2$ was determined in A427 and A549 cells by western blot assay after treatment with PEC at doses of 2, 4, 6, 8 and 10 $\mu \mathrm{M}$ for $48 \mathrm{~h}$. It was observed that PEC treatment caused suppression of ERK1/2 activation in a concentration-dependent manner. Although the suppression of ERK $1 / 2$ activation was significant at PEC doses $\geq 4 \mu \mathrm{M}$, maximum inhibition was observed at $8 \mu \mathrm{M}$ PEC (Figure 4).

\section{Effect of PD98059 on cell viability}

It was found that PD98059 treatment inhibited viabilities of both A-427 and A-549 cells to degrees comparable with the inhibition caused by PEC (Figure 5). These findings suggest that PEC inhibited viability of lung cancer cells by suppression of the activation of ERK1/2.

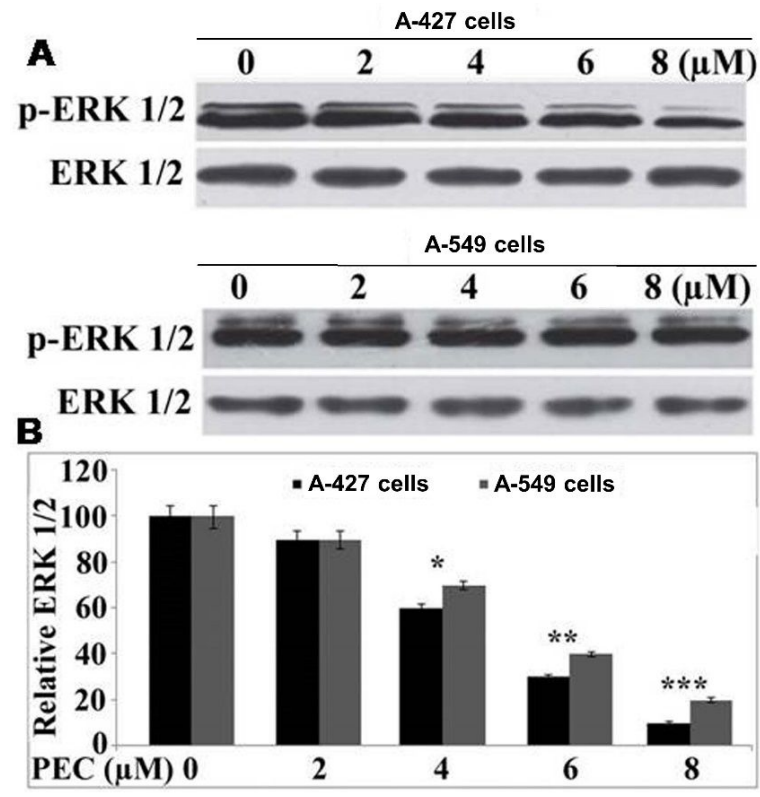

Figure 4: Inhibition of activation of ERK1/2 in A-427 and A-549 cells by PEC. After treating the cells with 2 , 4, 6, 8 and $10 \mu \mathrm{M}$ PEC for $48 \mathrm{~h}$, ERK1/2 activation was determined using western blot assay

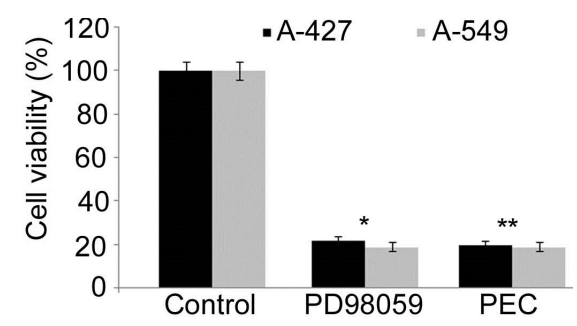

Figure 5: Inhibition of viabilities of A-427 and A-549 cells by PD98059. The cells were incubated with PD98059 for $48 \mathrm{~h}$ and viability was determined using MTT assay. ${ }^{*} p<0.05$, compared to the control cells.

\section{DISCUSSION}

Lung cancer is a challenge to clinicians, and has led to continuous studies aimed at developing more effective treatment strategies for the disease $[13,14]$. The present study investigated the effect of PEC on lung cancer cell viability and demonstrated the mechanism involved. It was found that PEC treatment inhibited the viability of lung cancer cells and induced their apoptosis. Further studies showed that the mechanism of inhibition of lung cancer cell proliferation by PEC involved suppression of ERK $1 / 2$ activation.

PEC treatment significantly inhibited the viability of lung cancer cells in concentration- and timedependent manners. Apoptosis is a cellular process associated with the destruction of unwanted cells, and it plays an important role in cancer treatment $[6,7]$. The regulation of apoptosis involves phosphorylation of various factors amongst which is ERK $1 / 2$ [8]. The 
present study showed that in lung cancer cells, treatment with PEC led to a markedly high degree of induction of apoptosis.

It is well known that cancer cell proliferation is promoted by the activation of MAPK pathway which at the same time inhibits cancer cell apoptosis [15]. Since ERK1/2 is a member of MAPK family, its phosphorylation increases the rate of proliferation of cancer cells [16]. The results obtained in the current study showed that activation of ERK $1 / 2$ in lung cancer cells was decreased by incubation with PEC. These findings suggest that PEC inhibits viability and induces apoptosis in lung cancer cells by targeting ERK1/2 activation.

Incubation of the lung cancer cells with PD98059 also reduced cell viability to levels comparable with those brought about by PEC. These findings confirm that PEC exhibits its effect in lung cancer cells by targeting the ERK1/2 pathway.

\section{CONCLUSION}

The results of the present study demonstrate that treatment of lung cancer cells with PEC inhibits their viabiliy and induces their apoptosis via down-regulation of the activation of ERK1/2. Therefore, PEC may be suitable for clinical application in the management of lung cancer.

\section{DECLARATIONS}

\section{Acknowledgement}

This study was supported by Science research project of Inner Mongolia University of nationalities (nos. NMDYB1719 and NMDYB1454) and The National Natural Science Foundation of China (no. 81373573).

\section{Conflict of interest}

The authors declare that no competing interest exists with regard to this work.

\section{Contribution of authors}

The authors declare that this work was done by done by the named authors and all liabilities pertaining to claims relating to the content of this article will be borne by them. Di Li, Lifei Li and Lingzhan Wang performed the experimental work. Jianguo $\mathrm{Li}$ and $\mathrm{Di} \mathrm{Li}$ carried out the literature study and compiled the data. Bin Zhang designed the study and wrote paper. The paper was thoroughly read by all the authors prior to its communication.

\section{REFERENCES}

1. Ahmedin J, Freddie B, Melissa M, Jacques $F$, Elizabeth W, David F. Global cancer statistics. CA Cancer J Clin 2011; 61: 69-90.

2. Fisher B, Costantino JP, Wickerham DL, Redmond CK, Kavanah M, Cronin WM. Tamoxifen for prevention of breast cancer: report of the National Surgical Adjuvant Breast and Bowel Project P-1 Study. J Natl Cancer Inst 1998; 90: 1371-1388.

3. Powles $T$, Eeles $R$, Ashley SE, Easton D, Chang J, Dowsett $L$. Interim analysis of the incidence of breast cancer in the Royal Marsden Hospital tamoxifen randomized chemoprevention trial. Lancet 1998; 352: 98-101.

4. Veronesi U, Maisonneuve P, Sacchini V, Rotmensz N, Boyle $P$. Tamoxifen for breast cancer among women hysterectomised. Lancet 2002; 359: 1122-1124.

5. Forbes JF, Cuzick J, Buzdar A, Howell A, Tobias JS, Baum M. Arimidex, tamoxifen, alone or in combination (ATAC) trialists' group. Effect of anastrozole and tamoxifen as adjuvant treatment for early-stage breast cancer: 100-month analysis of the ATAC trial. Lancet Oncol 2008; 9: 45-53.

6. Li Y, Brown PH. Prevention of ER-negative breast cancer. Recent Results Cancer Res 2009; 181: 121134.

7. Chen $Y$, Bieber MM, Teng NN. Hedgehog signaling regulates drug sensitivity by targeting $A B C$ transporters $A B C B 1$ and $A B C G 2$ in epithelial ovarian cancer. Mol Carcinog 2014; 53: 625-634.

8. Zhang $P$, Jia $R$, Ying L, Liu B, Qian G, Fan X, Ge S. WWOX国ediated apoptosis in A549 cells mainly involves the mitochondrial pathway. Mol Med Rep 2012; 6: 121-124.

9. Fiscella $M$, Zhang $H$, Fan $S$, Sakaguchi $K$, Shen $S$, Mercer WE, Vande Woude GF, O'Connor PM, Appella E. Wip1, a novel human protein phosphatase that is induced in response to ionizing radiation in a p53dependent manner. Proc Natl Acad Sci USA 1997; 94: 6048-6053.

10. Hirasawa A, Saito-Ohara F, Inoue J, Aoki D, Susumu N, Yokoyama $T$, Nozawa $S$, Inazawa J, Imoto $I$. Association of 17q21-q24 gain in ovarian clear cell adenocarcinomas with poor prognosis and identification of PPM1D and APPBP2 as likely amplification targets. Clin Cancer Res 2003; 9: 1995_2004.

11. Sun GG, Zhang J, Ma XB, Wang YD, Cheng YJ, Hu WN. Overexpression of Wild-Type p53-Induced Phosphatase 1 confers poor prognosis of patients with Nasopharyngeal Carcinoma. Pathol Oncol Res 2015; 21: 283291.

12. Sun GG, Wang YD, Liu Q, Hu WN. Expression of Wip1 in kidney carcinoma and its correlation with tumor metastasis and clinical significance. Pathol Oncol Res 2015; 21: 219 ॠ224.

13. Yanping F, Fang L, Zhixiang D, Dongjie Z, Jianxin C, Wei G. Wip1 regulates SKOV3 cell apoptosis through the

Trop J Pharm Res, October 2018; 17(10): 1923 
p38 MAPK signaling pathway. Mol Med reports 2017, 15: 3651-3657.

14. Li J, Yang Y, Peng Y, Austin RJ, van Eyndhoven WG, Nguyen KC, Gabriele T, McCurrach ME, Marks JR. Oncogenic properties of PPM1D located within a breast cancer amplification epicenter at 17q23. Nat Genet 2002; 31: 133-134.

15. Rauta J, Alarmo EL, Kauraniemi P, Karhu R, Kuukasjärvi $T$, Kallioniemi $A$. The serine-threonine protein phosphatase PPM1D is frequently activated through amplification in aggressive primary breast tumours. Breast Cancer Res Treat 2006; 95: 257-263.

16. Saito-Ohara F, Imoto I, Inoue J, Hosoi H, Nakagawara A, Sugimoto $T$, Inazawa J. PPM1D is a potential target for $17 q$ gain in neuroblastoma. Cancer Res 2003; 63: 1876 1883.

17. Tan DS, Lambros MB, Rayter S, Natrajan R, Vatcheva $R$, Gao Q, Marchiò C, Geyer FC, Savage K, Parry S. $P P M 1 D$ is a potential therapeutic target in ovarian clear cell carcinomas. Clin Cancer Res 2009; 15: 2269?2280.
18. Lee JS, Park JR, Kwon OS, Kim H, Fornace AJ Jr, Cha HJ. Off-target response of a Wip1 chemical inhibitor in skin keratinocytes. J Dermatol Sci 2014; 73: 125-134.

19. Yang $D H$, He JA, Li J, Ma WF, Hu XH, Xin SJ, Duan ZQ. Expression of proto-oncogene Wip1 in breast cancer and its clinical significance. Zhonghua Yi Xue Za Zhi 2010; 90: 519 2522.

20. Song JY, Ryu SH, Cho YM, Kim YS, Lee BM, Lee SW, Choi J. Wip1 suppresses apoptotic cell death through direct dephosphorylation of $B A X$ in response to $\gamma$ radiation. Cell Death Dis 2013; 4: e744.

21. Wang HY, Liu ZS, Qiu L, Guo J, Li YF, Zhang J, Wang $T J$, Liu XD. Knockdown of Wip1 enhances sensitivity to radiation in hela cells through activation of p38 MAPK. Oncol Res 2014; 22: 225-233.

22. Holnes WF, Soprano DR, Soprano KJ. Early events in the induction of apoptosis in ovarian carcinoma cells by CD437: Activation of the p38 MAP kinase signal pathway. Oncogene 2003; 22: 6377-6386. 